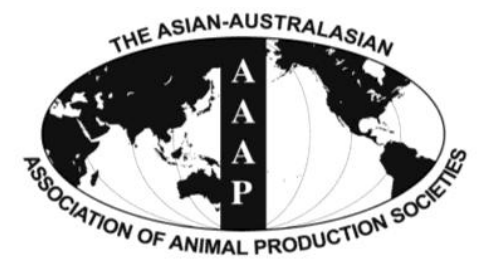

Asian Australas. J. Anim. Sci.

Vol. 26, No. 5 : 668-674 May 2013

http://dx.doi.org/10.5713/ajas.2012.12589

Www.ajas.info

pISSN $1011-2367$ elSSN 1976-5517

\title{
Effects of Dietary Supplementation with Hainanmycin on Protein Degradation and Populations of Ammonia-producing Bacteria In vitro
}

\author{
Z. B. Wang ${ }^{1,2, a}$, H. S. Xin ${ }^{1, a}$, M. J. Wang ${ }^{1}$, Z. Y. Li ${ }^{1}$, Y. L. Qu $^{2}$, S. J. Miao ${ }^{2}$ and Y. G. Zhang ${ }^{1, *}$ \\ ${ }^{1}$ College of Animal Science and Technology, Northeast Agricultural University, \\ Harbin, 150030, Heilongjiang, China
}

\begin{abstract}
An in vitro fermentation was conducted to determine the effects of hainanmycin on protein degradation and populations of ammonia-producing bacteria. The substrates (DM basis) for in vitro fermentation consisted of alfalfa hay (31.7\%), Chinese wild rye grass hay $(28.3 \%)$, ground corn grain $(24.5 \%)$, soybean meal $(15.5 \%)$ with a forage: concentrate of $60: 40$. Treatments were the control (no additive) and hainanmycin supplemented at 0.1 (H0.1), 1 (H1), 10 (H10), and $100 \mathrm{mg} / \mathrm{kg}$ (H100) of the substrates. After $24 \mathrm{~h}$ of fermentation, the highest addition level of hainanmycin decreased total VFA concentration and increased the final $\mathrm{pH}$. The high addition level of hainanmycin $(\mathrm{H} 1, \mathrm{H} 10$, and $\mathrm{H} 100)$ reduced $(\mathrm{p}<0.05)$ branched-chain VFA concentration, the molar proportion of acetate and butyrate, and ratio of acetate to propionate; and increased the molar proportion of propionate, except that for $\mathrm{H} 1$ the in molar proportion of acetate and isobutyrate was not changed ( $>0.05)$. After $24 \mathrm{~h}$ of fermentation, H10 and H100 increased $(\mathrm{p}<0.05)$ concentrations of peptide nitrogen and AA nitrogen and proteinase activity, and decreased $(\mathrm{p}<0.05) \mathrm{NH}_{3}-\mathrm{N}$ concentration and deaminase activity compared with control. Peptidase activitives were not affected by hainanmycin. Hainanmycin supplementation only inhibited the growth of Butyrivibrio fibrisolvens, which is one of the species of low deaminative activity. Hainanmycin supplementation also decreased $(\mathrm{p}<0.05)$ relative population sizes of hyper-ammonia-producing species, except for H0.1 on Clostridium aminophilum. It was concluded that dietary supplementation with hainanmycin could improve ruminal fermentation and modify protein degradation by changing population size of ammonia-producing bacteria in vitro; and the addition level of $10 \mathrm{mg} / \mathrm{kg}$ appeared to achieve the best results. (Key Words: Ammonia-producing Bacteria, Fermentation, Hainanmycin, Protein Degradation)
\end{abstract}

\section{INTRODUCTION}

Protein catabolism by ruminal microorganisms frequently leads to an excess of ammonia. A proportion of excess ammonia eventually is excreted as urea in the urine, which decreases the overall efficiency of nitrogen utilization by the animal (Tamminga, 1979; Leng and Nolan, 1984). Ammonia production is predominantly carried out by two categories of ammonia-producing bacteria (Wallace et al., 1997). One is comprised of the most numerous species of ruminal bacteria, which possess a low

\footnotetext{
* Corresponding Author: Y. G. Zhang. Tel: +86-0451-55190840, Fax: +86-0451-55190840, E-mail: zhangyonggen@ sina.com

${ }^{2}$ College of Animal Science and Technology, Heilongjiang Bayi Agricultural University, Daqing, 163319, China.

${ }^{a}$ Z. B. Wang and H. S. Xin contributed equally to this work and they are both co-first authors.

Submitted Oct. 22, 2012; Accepted Dec. 28, 2012; Revised Jan. 28, 2013
}

deaminative activity, and the other one is comprised of a much smaller population of so-called hyper-ammoniaproducing (HAP) bacteria, which have much higher deaminative activity (Chen and Russell, 1989; Attwood et al., 1998). Because of their high specific activities of ammonia production, the HAP bacteria are considered to deaminate over $25 \%$ of the protein in feeds (Krause and Russell, 1996).

Ionophores have significant effects on protein metabolism in the rumen. The ionophore monensin can decrease rumen ammonia production (Jalc and Laukova, 2002; Martineau et al., 2007; Ghorbani et al., 2008). It also may reduce protein degradation, but it appears mainly to affect deamination of AA in the rumen (Russell and Strobel, 1989). Monensin may inhibit HAP bacteria (Callaway et al., 1997). Much of the decrease in ruminal ammonia production caused by monensin addition can be specifically attributed to the inhibitory effects on HAP bacteria (Yang 
and Russell, 1993b; Krause and Russell, 1996; Uwituze et al., 2011).

Hainanmycin is an ionophore from one of the fermentation products of a rare streptomycete, Streptomyces padanus var dangfangeus, which is isolated from soil samples collected in Hainan province of China. The usage of hainanmycin in animal feed has been permitted by the State Food and Drug Administration (SFDA) of China since 1993. Hainanmycin can reduce ammonia production (Ren et al., 1998). However, there is little information on the effects of dietary supplementation of hainanmycin on protein degradation and populations of ammonia-producing bacteria in the rumen. The objective of the present study was to evaluate the effects of different supplementation levels of hainanmycin on protein degradation and populations of ammonia-producing bacteria in in vitro study.

\section{MATERIAL AND METHODS}

\section{Rumen fermentation in vitro}

In vitro fermentation was carried out according to the procedure described by Menke et al. (1979). Rumen fluid was obtained from two ruminally-fistulated heifers fed a 60:40 (forage:concentrate) diet (Table 1) which was formulated to meet NRC (2001) nutrient requirements for heifers. All procedures involving animals were conducted under the approval of Northeast Agricultural University Animal Science and Technology College Animal Care and Use Committee. Rumen fluid was strained through two layers of cheesecloth, and mixed in a 1:2 proportion with buffer (Menke et al., 1979). The fermentation process was conducted in $90 \mathrm{ml}$ glasses syringes containing $50 \mathrm{ml}$ of culture fluid with $0.5 \mathrm{~g}$ of a substrate ground through a 1 $\mathrm{mm}$ screen. The substrate (DM basis) consisted of alfalfa hay $(31.7 \%)$, Chinese wild rye grass hay $(28.3 \%)$, ground

Table 1. Ingredients and chemical composition of diet

\begin{tabular}{lr}
\hline Composition & $\%$ \\
\hline Ingredient (\% of DM) & \\
Corn grain, ground & 23.80 \\
Soybean meal & 15.50 \\
Alfalfa & 31.70 \\
Chinese wild rye grass & 28.40 \\
Monobasic sodium phosphate & 0.40 \\
Salt & 0.30 \\
Vitamin and mineral mixture ${ }^{1}$ & 0.40 \\
Chemical composition & \\
CP (\% of DM) & 17.50 \\
NDF (\% of DM) & 34.80 \\
ADF (\% of DM) & 22.30 \\
\hline
\end{tabular}

${ }^{1}$ Contained (per kg): $7 \mathrm{mg}$ of $\mathrm{Co} ; 167 \mathrm{mg}$ of $\mathrm{Cu} ; 33 \mathrm{mg}$ of I; $2,660 \mathrm{mg}$ of $\mathrm{Mn} ; 27 \mathrm{mg}$ of Se; 4,660 mg of Zn; 1,000 kIU of vitamin A; $200 \mathrm{kIU}$ of vitamin $\mathrm{D}_{3} ; 1,330 \mathrm{mg}$ of vitamin $\mathrm{E} ; 33 \mathrm{~g}$ of sulfur; and $300 \mathrm{~g}$ of $\mathrm{MgO}$. corn grain $(24.5 \%)$ and soybean meal $(15.5 \%)$. The 1,10 , 100 , and 1,000 mg of hainanmycin (Shandong Sheng li Co., Ltd.; $\mathrm{C}_{47} \mathrm{H}_{80} \mathrm{O}_{15} \cdot \mathrm{H}_{2} \mathrm{O}$, purity of $99 \%$ ) were dissolved in $10 \mathrm{~L}$ ethanol, respectively, and a total of $0.5 \mathrm{ml}$ was added to the culture fluid (designed as H0.1, H1, H10, and H100, respectively). And $0.5 \mathrm{ml}$ of ethanol (without any additive) was also added to the culture fluid in the control. Each syringe was gassed with carbon dioxide $\left(\mathrm{CO}_{2}\right)$ before sealing with rubber corks with a gas release valve. Syringes were incubated in a water bath at $39^{\circ} \mathrm{C}$. The in vitro incubation was done 2 times in triplicate each time under similar conditions.

\section{Sample collection}

After $24 \mathrm{~h}$ incubation, ruminal $\mathrm{pH}$ was measured immediately by Mettler Delta 340 (Mettler Electronics, UK) and subsamples were acidified to $\mathrm{pH} 2$ with sulfuric acid (50\% vol/vol; 1:17 wt/wt acid: rumen fluid) and frozen at $-20^{\circ} \mathrm{C}$ for later determination of VFA and ammonia $\mathrm{N}$ concentrations. Samples were also taken for determination of peptide nitrogen $(\mathrm{N})$, AA N, proteinase, peptidase, and deaminase, and isolation of DNA or RNA.

\section{Chemical analysis}

Thawed ruminal samples were prepared for analysis by centrifuging at $30,000 \mathrm{~g}$ for $15 \mathrm{~min}$ at $4^{\circ} \mathrm{C}$ and then supernatant was collected. Concentrations of VFA were measured using gas chromatography. The procedure of Broderick and Kang (1980) was used to measure concentrations of ammonia. Peptide $\mathrm{N}$ and AA N were determined as described by Winter et al. (1964).

Proteinase, peptidase, and deaminase activities were measured by using mixed ruminal bacteria from fermentation fluid after $24 \mathrm{~h}$ incubation, prepared by straining and centrifuging at $200 \mathrm{~g}$ for $15 \mathrm{~min}$ in order to remove ciliate protozoa. Proteinase activity used ${ }^{14} \mathrm{C}$ labelled casein as previously described with whole bacteria (Wallace, 1983), while peptidase (dipeptidyl peptidases and dipeptidases) assays used GlyArg- $p$-nitroanilide (pNA), GlyPro-pNA, Ala 2 -pNA, LeuN-pNA, and Pro-pNA and sonicated bacteria by measuring peptide breakdown by reverse-phase high-performance liquid chromatography (Wallace and McKain, 1989). Deaminase activity was measured by using casein acid hydrolysate as the substrate (Newbold et al., 1990).

Procedures for DNA extraction, PCR reactions, and calculation of relative population sizes (RPS) based on $16 \mathrm{~S}$ rRNA gene copy number have been described by Stevenson and Weimer (2007). PCR primers for the following taxa have been described previously (Stevenson and Weimer, 2007): Butyrivibrio fibrisolven, Prevotella ruminicola, Megasphaera elsdenii, Selenomonas ruminantium, and 
Streptococcus bovis. The RPS of these species are expressed as percentages of the $16 \mathrm{~S}$ rRNA gene copy number of the total bacterial domain.

The rRNA was extracted from cells in rumen samples by bead beating with a Mini-bead beater (Biospec Products, Bartlesville, Okla) as described by Stahl et al. (1988). Hybridization process and the probe sequences used for hyper-ammonia-producing (HAP) bacteria (Clostridium aminophilum, Peptostreptococcus anaerobius, and Clostridium Sticklandii) have been described previously (Krause and Russell, 1996). The relative amount of 16S rRNA was determined with a universal probe (5'CCTGTGTCGGTT-3'), and the amounts of $C$. aminophilum, $P$. anaerobius, and $C$. sticklandii $16 \mathrm{~S}$ rRNAs were estimated from hybridization intensity standard curves.

\section{Statistical analyses}

The effects of different levels of dietary supplementation with hainanmycin compared with control were tested using the General Linear Model (GLM) procedure of SAS (version 8.12, SAS Institute, 1989). We had a total ten observations ( 5 treatment $\times 2$ times) in the present study and the observations were subjected to least squares analysis of variance according to the following models:

$$
\mathrm{Y}_{\mathrm{ij}}=\mu+\tau_{\mathrm{i}}+\mathrm{S}_{\mathrm{j}}+\varepsilon_{\mathrm{ij}}
$$

Where $Y_{i j}$ is dependent variable, $\mu$ is the overall mean, $\tau_{\mathrm{i}}$ is the effect of treatment ( $\mathrm{i}=5$ ), $\mathrm{S}_{\mathrm{j}}$ is the random effect of repeated time $(\mathrm{j}=3)$, and $\varepsilon_{\mathrm{j}}$ is the error term.

When the overall $F$-test was significant, differences between means and the control were declared significant at $\mathrm{p}<0.05$ using the Duncan's New Multiple Range Test.

\section{RESULTS}

\section{Rumen fermentation characteristics in vitro}

Dietary supplementation with different levels of hainanmycin had no effect on $\mathrm{pH}(\mathrm{p}<0.05)$ with the exception of the level of $100 \mathrm{mg} / \mathrm{kg}$ (Table 2), which increased $\mathrm{pH}$ by $9.92 \%(\mathrm{p}<0.05)$ when compared with control. Treatment H100 reduced total VFA concentration by $47.16 \%(p<0.05)$, but other levels of hainanmycin had no effect on total VFA content. Increasing addition levels of hainanmycin (higher than $1 \mathrm{mg} / \mathrm{kg}$ ) significantly decreased acetate molar percentage $(\mathrm{p}<0.05)$ and increased propionate molar percentage $(p<0.05)$, which led to the reduced ratio of acetate to propionate. Treatments $\mathrm{H} 10$ and $\mathrm{H} 100$ had a reduced molar percentage of butyrate $(p<0.05)$ and there were no difference among treatments on valerate concentration $(\mathrm{p}>0.05)$. The molar percentage of isobutyrate and isovalerate and branched-chain VFA decreased as the level of hainanmycin supplementation increased.

\section{$\mathbf{N}$ fraction concentrations of protein degradation in vitro}

Peptide $\mathrm{N}$ concentration was increased $(\mathrm{p}<0.05)$ in treatment $\mathrm{H} 10$ and $\mathrm{H} 100$ compared with the control (Table 3 ). Increasing the addition level of hainanmycin (higher than $0.1 \mathrm{mg} / \mathrm{kg})$ significantly increased $(\mathrm{p}<0.05)$ AA $\mathrm{N}$ concentration compared with control. When hainanmycin was added at levels of 1,10 , and $100 \mathrm{mg} / \mathrm{kg}, \mathrm{NH}_{3}-\mathrm{N}$ concentration declined by 23.96, 32.05, and $47.39 \%$, respectively.

\section{Proteinase, peptidase, and deaminase activities in vitro}

Treatment H10 and H100 increased $(\mathrm{p}<0.05)$ proteinase activity compared with control (Table 3). The Peptidase activities were similar among treatments. Deaminase activity declined $(\mathrm{p}<0.05)$ in $\mathrm{H} 1, \mathrm{H} 10$, and $\mathrm{H} 100$ when

Table 2. Effects of dietary supplementation with hainanmycin on $\mathrm{pH}$, total VFA, and individual VFA concentrations in vitro

\begin{tabular}{|c|c|c|c|c|c|c|c|}
\hline \multirow{2}{*}{ Item } & \multicolumn{5}{|c|}{ Treatment $^{1}$} & \multirow{2}{*}{ SEM } & \multirow{2}{*}{$\operatorname{Pr}>F^{3}$} \\
\hline & Control & H0.1 & $\mathrm{H} 1$ & H10 & H100 & & \\
\hline$\overline{\mathrm{pH}}$ & $6.45^{\mathrm{b}}$ & $6.46^{\mathrm{b}}$ & $6.41^{\mathrm{b}}$ & $6.49^{\mathrm{b}}$ & $7.16^{\mathrm{a}}$ & 0.05 & * \\
\hline Total VFA (Mm) & $139.53^{\mathrm{a}}$ & $138.37^{\mathrm{a}}$ & $143.53^{\mathrm{a}}$ & $135.96^{\mathrm{a}}$ & $73.72^{\mathrm{b}}$ & 4.56 & * \\
\hline \multicolumn{8}{|l|}{ VFA $(\mathrm{mol} / 100 \mathrm{~mol})$} \\
\hline Acetate & $64.88^{\mathrm{a}}$ & $64.35^{\mathrm{a}}$ & $57.10^{\mathrm{a}}$ & $48.66^{\mathrm{b}}$ & $46.41^{\mathrm{b}}$ & 2.27 & * \\
\hline Propionate & $19.31^{\mathrm{c}}$ & $20.33^{\mathrm{c}}$ & $30.23^{\mathrm{b}}$ & $40.94^{\mathrm{a}}$ & $45.43^{\mathrm{a}}$ & 2.49 & * \\
\hline Butyrate & $10.23^{\mathrm{a}}$ & $9.75^{\mathrm{a}}$ & $8.85^{\mathrm{ab}}$ & $6.66^{\mathrm{bc}}$ & $4.62^{\mathrm{c}}$ & 0.75 & * \\
\hline Valerate & 2.60 & 2.56 & 2.65 & 2.55 & 2.62 & 0.19 & NS \\
\hline Isobutyrate & $0.59^{\mathrm{a}}$ & $0.58^{\mathrm{a}}$ & $0.40^{\mathrm{ab}}$ & $0.27^{\mathrm{bc}}$ & $0.19^{\mathrm{c}}$ & 0.05 & $*$ \\
\hline Isovalerate & $2.39^{\mathrm{a}}$ & $2.43^{\mathrm{a}}$ & $0.77^{\mathrm{b}}$ & $0.62^{\mathrm{b}}$ & $0.53^{\mathrm{b}}$ & 0.35 & * \\
\hline $\mathrm{BCVFA}^{2}(\mathrm{Mm})$ & $4.17^{\mathrm{a}}$ & $4.17^{\mathrm{a}}$ & $1.62^{\mathrm{b}}$ & $1.31^{\mathrm{b}}$ & $0.55^{\mathrm{b}}$ & 0.57 & * \\
\hline Acetate/propionate & $3.41^{\mathrm{a}}$ & $3.19^{\mathrm{a}}$ & $1.90^{\mathrm{b}}$ & $1.19^{\mathrm{b}}$ & $1.02^{\mathrm{b}}$ & 0.23 & * \\
\hline
\end{tabular}

${ }^{1} \mathrm{H} 0.1=0.1 \mathrm{mg} / \mathrm{kg}$ of hainanmycin; H1 = $1 \mathrm{mg} / \mathrm{kg}$ of hainanmycin; H10 =10 mg/kg of hainanmycin; H100 = $100 \mathrm{mg} / \mathrm{kg}$ of hainanmycin.

${ }^{2}$ Branched-chain VFA; includes isobutyrate and isovalerate. ${ }^{3} \mathrm{Pr}>\mathrm{F}=$ Probability level.

${ }^{\mathrm{a}, \mathrm{b}, \mathrm{c}}$ Within a row, means with the superscript differ from each other.

$* \mathrm{p}<0.05 ; \mathrm{NS}=$ Not significant; SEM = Standard error of the mean. 
Table 3. Effects of dietary supplementation with hainanmycin on $\mathrm{N}$ fraction concentrations, proteinase, peptidase, and deaminase activities in vitro

\begin{tabular}{|c|c|c|c|c|c|c|c|}
\hline \multirow{2}{*}{ Item } & \multicolumn{5}{|c|}{ Treatment $^{1}$} & \multirow{2}{*}{ SEM } & \multirow{2}{*}{$\operatorname{Pr}>\mathrm{F}$} \\
\hline & Control & H0.1 & H1 & H10 & H100 & & \\
\hline Peptide N (mg/dl) & $8.22^{\mathrm{c}}$ & $8.03^{\mathrm{c}}$ & $9.14^{\mathrm{bc}}$ & $12.19^{\mathrm{ab}}$ & $13.67^{\mathrm{a}}$ & 1.03 & $*$ \\
\hline Amino acid $\mathrm{N}(\mathrm{mg} / \mathrm{dl})$ & $7.07^{\mathrm{c}}$ & $7.99^{\mathrm{bc}}$ & $11.32^{\mathrm{ab}}$ & $13.08^{\mathrm{a}}$ & $14.99^{\mathrm{a}}$ & 1.08 & $*$ \\
\hline $\mathrm{NH}_{3}-\mathrm{N}(\mathrm{mg} / \mathrm{dl})$ & $22.62^{\mathrm{a}}$ & $22.26^{\mathrm{a}}$ & $17.20^{\mathrm{b}}$ & $15.37^{\mathrm{bc}}$ & $11.90^{\mathrm{c}}$ & 1.21 & $*$ \\
\hline Proteinase activity $^{2}$ & $0.57^{\mathrm{b}}$ & $0.58^{\mathrm{b}}$ & $0.66^{\mathrm{b}}$ & $0.78^{\mathrm{a}}$ & $0.74^{\mathrm{a}}$ & 0.04 & $*$ \\
\hline \multicolumn{8}{|l|}{ Peptidase activity ${ }^{3}$} \\
\hline GlyArg-pNA & 1.42 & 1.41 & 1.34 & 1.38 & 1.48 & 0.05 & NS \\
\hline GlyPro-pNA & 2.38 & 2.44 & 2.26 & 2.27 & 2.34 & 0.06 & NS \\
\hline $\mathrm{Ala}_{2}$-pNA & 4.78 & 4.92 & 2.23 & 2.27 & 2.29 & 0.09 & NS \\
\hline Leu-pNA & 0.24 & 0.19 & 0.21 & 0.23 & 0.27 & 0.03 & NS \\
\hline Pro-pNA & 0.89 & 0.88 & 0.95 & 0.93 & 0.93 & 0.04 & NS \\
\hline Deaminase activity $^{4}$ & $406^{\mathrm{a}}$ & $390^{\mathrm{a}}$ & $352^{\mathrm{b}}$ & $177^{\mathrm{c}}$ & $164^{c}$ & 11.24 & $*$ \\
\hline
\end{tabular}

${ }^{\mathrm{T}} \mathrm{H} 0.1=0.1 \mathrm{mg} / \mathrm{kg}$ of hainanmycin; $\mathrm{H} 1=1 \mathrm{mg} / \mathrm{kg}$ of hainanmycin; $\mathrm{H} 10=10 \mathrm{mg} / \mathrm{kg}$ of hainanmycin; $\mathrm{H} 100=100 \mathrm{mg} / \mathrm{kg}$ of hainanmycin.

${ }^{2} \mathrm{mg}$ of ${ }^{14} \mathrm{C}$-casein hydrolyzed $\mathrm{h}^{-1} \mathrm{mg}$ of protein ${ }^{-1} .{ }^{3} \mathrm{nmol} \min ^{-1} \mathrm{mg}$ of protein ${ }^{-1} .{ }^{4} \mathrm{nmol}$ of ammonia produced $\mathrm{h}^{-1} \mathrm{mg}_{\text {of }}$ protein ${ }^{-1}$.

${ }^{\mathrm{a}, \mathrm{b}, \mathrm{c}}$ Means within a row with the superscript differ from each other. $\operatorname{Pr}>\mathrm{F}=$ Probability level.

$* \mathrm{p}<0.05 ; \mathrm{NS}=$ Not significant; $\mathrm{SEM}=$ Standard error of the mean.

compared with control.

\section{Relative population sizes (RPS) of ammonia-producing bacteria in vitro}

Treatment $\mathrm{H} 10$ and $\mathrm{H} 100$ reduced $(\mathrm{p}<0.05)$ RPS of Butyrivibrio fibrisolvens and increased $(\mathrm{p}<0.05)$ RPS of Prevotella ruminicola compared with control (Table 4). Different levels of hainanmycin had no effect on RPS of Megasphaera elsdenii, Selenomonas ruminantium, and Streptococcus bovis (not detected). In addition, hainanmycin supplementation decreased $(\mathrm{p}<0.05)$ RPS of $C$. aminophilum, $P$. anaerobius and $C$. sticklandii, except for H0.1 on C. aminophilum compared with control (Table 5).

\section{DISCUSSION}

\section{Effects of dietary supplementation with hainanmycin on ruminal fermentation}

Hainanmycin supplemented at $100 \mathrm{mg} / \mathrm{kg}$ increased $\mathrm{pH}$ to 7.16, which indicated the fermentation of substrate was inhibited. Volatile fatty acids are the end products of rumen microbial fermentation and represent the main supply of metabolizable energy for ruminants (Van Soest, 1994). Therefore, a reduction in their production would be nutritionally unfavorable for the animal. In our study, hainanmycin added at $100 \mathrm{mg} / \mathrm{kg}$ decreased total VFA concentration. Compared with the control, total VFA concentration and $\mathrm{pH}$ were not changed by other levels (H0.1, H1, and H10) of hainanmycin supplementation. Similar to the results in the present trial with hainanmycin, Ren et al. (1998) reported the supplementation of $2.0 \mathrm{mg} / \mathrm{kg}$ of hainanmycin (estimated ruminal concentration) had no effect on total VFA concentration compared with control.

Changes in molar percentages of acetate, propionate and their ratio in the present study were in agreement with the observations of Ren et al. (1998), who reported that dietary addition of hainanmycin increased $(\mathrm{p}<0.05)$ the molar proportions of propionate from $21.8 \%$ to $26.3 \%$ and decreased $(\mathrm{p}<0.05)$ that of acetate from $72.8 \%$ to $68.8 \%$ and the ratio of acetate to propionate. Lower ratio of acetate and propionate reflects a shift in ruminal fermentation that is more efficient for beef production systems (Wolin and Miller, 1988; Brockman, 1993). The proportions of individual VFA were not affected by supplementation of

Table 4. Effects of dietary supplementation with hainanmycin on the relative ruminal population sizes (RPS) of four ammonia-producing bacteria in vitro ${ }^{1}$

\begin{tabular}{|c|c|c|c|c|c|c|c|}
\hline \multirow{2}{*}{ Item } & \multicolumn{5}{|c|}{ Treatment $^{2}$} & \multirow{2}{*}{ SEM } & \multirow{2}{*}{$\operatorname{Pr}>F^{3}$} \\
\hline & Control & H0.1 & H1 & $\mathrm{H} 10$ & $\mathrm{H} 100$ & & \\
\hline Butyrivibrio fibrisolvens & $0.024^{\mathrm{a}}$ & $0.025^{\mathrm{a}}$ & $0.023^{\mathrm{a}}$ & $0.012^{\mathrm{b}}$ & $0.012^{\mathrm{b}}$ & 0.002 & $*$ \\
\hline Prevotella ruminicola & $0.69^{c}$ & $1.13^{b c}$ & $1.20^{\mathrm{bc}}$ & $2.56^{\mathrm{ab}}$ & $2.89^{\mathrm{a}}$ & 0.41 & $*$ \\
\hline Megasphaera elsdenii & 0.31 & 0.34 & 0.31 & 0.28 & 0.32 & 0.04 & NS \\
\hline Selenomonas ruminantium & 0.52 & 0.54 & 0.51 & 0.59 & 0.60 & 0.05 & NS \\
\hline
\end{tabular}

${ }^{1}$ RPS are expressed as percentages (\%) of the $16 \mathrm{~S}$ rRNA gene copy number of the total bacterial domain.

${ }^{2} \mathrm{H} 0.1=0.1 \mathrm{mg} / \mathrm{kg}$ of hainanmycin; $\mathrm{H} 1=1 \mathrm{mg} / \mathrm{kg}$ of hainanmycin; $\mathrm{H} 10=10 \mathrm{mg} / \mathrm{kg}$ of hainanmycin; H100 = $100 \mathrm{mg} / \mathrm{kg}$ of hainanmycin.

${ }^{3} \mathrm{Pr}>\mathrm{F}=$ Probability level.

${ }^{\mathrm{a}, \mathrm{b}, \mathrm{c}}$ Means within a row with the superscript differ from each other.

$* \mathrm{p}<0.05 ; \mathrm{NS}=$ Not significant; $\mathrm{SEM}=$ Standard error of the mean. 
Table 5. Effects of dietary supplementation with hainanmycin on the relative ruminal population sizes (RPS) of hyper-ammoniaproducing (HAP) bacteria in vitro ${ }^{1}$

\begin{tabular}{|c|c|c|c|c|c|c|c|}
\hline \multirow{2}{*}{ Item } & \multicolumn{5}{|c|}{ Treatment $^{2}$} & \multirow{2}{*}{ SEM } & \multirow{2}{*}{$\operatorname{Pr}>F^{3}$} \\
\hline & Control & H0.1 & $\mathrm{H} 1$ & H10 & $\mathrm{H} 100$ & & \\
\hline Clostridium aminophilum & $1.01^{\mathrm{a}}$ & $1.04^{\mathrm{a}}$ & $0.77^{\mathrm{b}}$ & $0.08^{\mathrm{c}}$ & $0.09^{\mathrm{c}}$ & 0.03 & $*$ \\
\hline Peptostreptococcus anaerobius & $1.08^{\mathrm{a}}$ & $0.40^{\mathrm{b}}$ & $0.15^{\mathrm{c}}$ & $0.06^{\mathrm{c}}$ & $0.06^{\mathrm{c}}$ & 0.04 & $*$ \\
\hline Clostridium sticklandii & $1.17^{\mathrm{a}}$ & $0.33^{\mathrm{b}}$ & $0.16^{\mathrm{c}}$ & $0.08^{\mathrm{c}}$ & $0.06^{\mathrm{c}}$ & 0.35 & $*$ \\
\hline
\end{tabular}

${ }^{1}$ RPS are expressed as percentages (\%) of the 16S rRNA gene copy number of the total bacterial domain.

${ }^{2} \mathrm{H} 0.1=0.1 \mathrm{mg} / \mathrm{kg}$ of hainanmycin; $\mathrm{H} 1=1 \mathrm{mg} / \mathrm{kg}$ of hainanmycin; $\mathrm{H} 10=10 \mathrm{mg} / \mathrm{kg}$ of hainanmycin; H100 = $100 \mathrm{mg} / \mathrm{kg}$ of hainanmycin.

${ }^{3} \mathrm{Pr}>\mathrm{F}=$ Probability level.

${ }^{\mathrm{a}, \mathrm{b}, \mathrm{c}}$ Means within a row with the superscript differ from each other.

$* \mathrm{p}<0.05 ; \mathrm{NS}=$ Not significant; SEM = Standard error of the mean.

hainamycin at $0.1 \mathrm{mg} / \mathrm{kg}$ compared with control. Treatment $\mathrm{H} 10$ and $\mathrm{H} 100$ decreased molar percentage of butyrate. The bacterium Butyrivibrio fibrisolvens is considered as a major producer of butyrate in the rumen (Miller and Jenesel, 1979). The decrease in molar percentage of butyrate in the present experiment might result from the reduction of this species.

The branched-chain VFA (BCVFA) is derived from amino acid catabolism in the rumen (Mackie and White, 1990). The observed reduction in BCVFA (isobutyrate and isovalerate) concentration in $\mathrm{H} 1, \mathrm{H} 10$, and $\mathrm{H} 100$ implied that hainanmycin supplemented at $1.0,10$, and $100 \mathrm{mg} / \mathrm{kg}$ inhibited amino acid deamination.

\section{Effects of dietary supplementation with hainanmycin on ruminal protein degradation}

Treatment $\mathrm{H} 10$ and $\mathrm{H} 100$ increased peptide $\mathrm{N}$ concentration by $33.66 \%$ and $46.44 \%$, respectively, which suggested that proteolysis was stimulated or peptidolysis was inhibited when hainanmycin was added at 10 and 100 $\mathrm{mg} / \mathrm{kg}$. Addition of hainanmycin at 1,10 , and $100 \mathrm{mg} / \mathrm{kg}$ resulted in higher AA N concentration and lower $\mathrm{NH}_{3}-\mathrm{N}$ concentration. The accumulation of AA N and the decrease in $\mathrm{NH}_{3}-\mathrm{N}$ implied that amino acid deamination could be inhibited. The inhibition of amino acid deamination has practical implications because it may increase ruminal escape of dietary protein and improve the efficiency of $\mathrm{N}$ use in the rumen (Van Nevel and Demeyer, 1988).

H10 and H100 increased proteinase activity. Similarly, steers fed monensin and tylosin (a kind of ionophore) tended $(\mathrm{p}<0.08)$ to have greater in vitro protease activity than steers in the control. In contrast, monensin decreased protein disappearance in vitro, which indicated that proteinase activity was inhibited (Van Nevel and Demeyer, 1977; Whetstone et al., 1981). All levels of hainanmycin addition had no effect on peptidase activities, which indicated that hainanmycin supplementation failed to affect degradation of peptides to amino acids. The increase in proteinase activity and the lack of affect of hainanmycin supplementation on peptidase activity were consistent with the result of an increase in the peptide $\mathrm{N}$ concentration.
Different addition levels of hainanmycin decreased deaminase activity with the exception of the level of 0.1 $\mathrm{mg} / \mathrm{kg}$, which corresponded with the increase in AA $\mathrm{N}$ concentration and the decrease in $\mathrm{NH}_{3}-\mathrm{N}$.

\section{Effects of dietary supplementation with hainanmycin on populations of ammonia-producing bacteria}

Ionophore sensitivity is closely correlated with cell wall structure. Gram-negative bacteria have an outer membrane that keeps monensin from reaching the cell membrane, but gram-positive bacteria are lacking in this defense mechanism and are generally more sensitive (Russell and Strobel, 1989). Treatment H10 and H100 reduced relative population sizes (RPS) of $B$. fibrisolvens during incubation, which may result from the fact that $B$. fibrisolvens as grampositive bacteria is sensitive to ionophores. The RPS of $P$. ruminicola was increased in $\mathrm{H} 10$ and $\mathrm{H} 100$, which was similar to the results of Weimer et al. (2008) who observed that dietary supplementation of monensin increased relative ruminal population sizes of $P$. ruminicola during rumen fermentation of lactating dairy cows. P. ruminicola is also the predominant species of proteolytic bacterium in the rumen (van Gylswyk, 1990). Increases in proteinase activity and peptide $\mathrm{N}$ concentration may originate from the increasing RPS of $P$. ruminicola. The different addition levels of hainanmycin had no effect on the number of $M$. Elsdenii and $S$. ruminantium. These two bacteria are gramnegative bacteria, thus the ionophore hainanmycin failed to affect them. In contrast, RPS of $C$. aminophilum, $P$. anaerobius, and $C$. sticklandii decreased remarkably as the inclusion level of hainanmycin supplementation increased, which agreed with the former result of lower ammonia concentration. Similarly, Yang and Russell (1993a; b) demonstrated that the decrease in ruminal ammonia caused by monensin supplementation was associated with a tenfold decrease in hyper-ammonia-producing (HAP) bacteria. Chen and Russell (1989) reported that monensin reduced $\mathrm{NH}_{3}-\mathrm{N}$ concentration through the inhibition of the HAP bacteria responsible for the production of most of the ammonia. Hainanmycin decreased RPS of C. aminophilum, except for the lowest addition level in the present study, 
which suggested $C$. aminophilum was sensitive to hainanmycin in vitro. Krause and Russell (1996) also found that $C$. aminophilum was sensitive to monensin in a batch culture system, but $C$. aminophilum could survive in the rumen or continuous culture system after monensin was added to the diet. Callaway et al. (1999) also reported that $C$. aminophilum was highly sensitive to monensin upon first exposure, but was able to increase their resistance significantly to monensin following repeated exposures. These two studies suggest that there exists potential adaptation of $C$. aminophilum to monensin during longterm fermentation or in vivo. The $C$. aminophilum may also have the potential to adapt to hainanmycin since hainanmycin has property similar to monensin. Therefore, further studies are required to define effects of hainanmycin on $C$. aminophilum in continuous culture or in vivo. The high addition level (10 and $100 \mathrm{mg} / \mathrm{kg}$ ) of hainanmycin almost eliminated $P$. anaerobius and $C$. sticklandii. Similarly, Callaway et al. (1997) found that RPS of $P$. anaerobius or $C$. sticklandii declined to undetectable amounts when animals were fed monensin. Krause and Russell (1996) also obtained similar results.

\section{CONCLUSIONS}

Dietary supplementation with hainanmycin could improve ruminal fermentation and modify protein degradation by changing the population size of ammoniaproducing bacteria. Taking ruminal fermentation, protein degradation, and populations of ammonia-producing bacteria into consideration, the optimal addition level is 10 $\mathrm{mg} / \mathrm{kg}$ of hainanmycin in vitro.

\section{ACKNOWLEDGEMENTS}

The authors are grateful to Industry Technology System of Modern Agriculture (Dairy Cattle) and Technology Project from Education Department of Heilongjiang Province (12511036) for providing financial support for this project.

\section{REFERENCES}

Brockman, R. P. 1993. Glucose and short-chain fatty acid metabolism. In: Quantitative Aspects of Ruminant Digestion and Metabolism (Ed. J. M. Forbes and J. France). CAB International, London, UK. pp. 249-265.

Broderick, G. A. and J. H. Kang. 1980. Automated simultaneous determination of ammonia and total amino acids in ruminal fluid and in vitro media. J. Dairy Sci. 63:64-75.

Callaway, T. R., K. A. Adams and J. B. Russell. 1999. The ability of "low G+C gram-positive" ruminal bacteria to resist monensin and counteract potassium depletion. Curr. Microbiol. 39:226-230.
Callaway, T. R., A. M. Carneiro De Melo and J. B. Russell. 1997. The effect of nisin and monensin on ruminal fermentations in vitro. Curr. Microbiol. 35:90-96.

Chen, G. and J. B. Russell. 1989. More monensin-sensitive, ammonia-producing bacteria from the rumen. Appl. Environ. Microbiol. 55:1052-1057.

Ghorbani, B., T. Ghoorchi, H. Amanlou and S. Zerehdaran. 2008. Effects of monensin and increasing crude protein in early lactation on performance of dairy cows. Pak. J. Biol. Sci. 11:1669-1675.

Jalc, D. and A. Laukova. 2002. Effect of nisin and monensin on rumen fermentation in the artificial rumen. Berl. Munch. Tierarztl. Wochenschr. 115:6-10.

Krause, D. O. and J. B. Russell. 1996. An rRNA approach for assessing the role of obligate amino acid-fermenting bacteria in ruminal amino acid deamination. Appl. Environ. Microbiol. 62:815-821.

Leng, R. A. and J. V. Nolan. 1984. Nitrogen metabolism in the rumen. J. Dairy Sci. 67:1072-1089.

Mackie, R. I. and B. A. White. 1990. Recent advances in rumen microbial ecology and metabolism: potential impact on nutrient output. J. Dairy Sci. 73:2971-2995.

Martineau, R., C. Benchaar, H. V. Petit, H. Lapierre, D. R. Ouellet, D. Pellerin and R. Berthiaume. 2007. Effects of lasalocid or monensin supplementation on digestion, ruminal fermentation, blood metabolites, and milk production of lactating dairy cows. J. Dairy Sci. 90:5714-5725.

Menke, K. H., L. Raab, A. Salewski, H. Steingass, D. Fritz and W. Schneider. 1979. The estimation of the digestibility and metabolizable energy content of ruminant feedingstuffs from the gas production when they are incubated with rumen liquor in vitro. J. Agric. Sci. 93:217-222.

Miller, T. L. and S. E. Jenesel. 1979. Enzymology of butyrate formation by Butyrivibrio fibrisolvens. J. Bacteriol. 138:99104.

Newbold, C. J., R. J. Wallace and N. McKain. 1990. Effects of the ionophore tetronasin on nitrogen metabolism by ruminal microorganisms in vitro. J. Anim. Sci. 68:1103-1109.

NRC. 2001. Nutrient requirements of dairy cattle. 7th Rev. Ed. National Academy Press, Washington, DC, USA.

Ren, M. Q., Z. M. Shen, R. Q. Zhao, T. S. Lu and J. Chen. 1998. Effects of novel polyether ionophore hainanmycin on nutrient digestion, metabolism and ruminal characteristics of goats. J. Anim. Feed Sci. 7:21-28.

Russell, J. B. and H. J. Strobel. 1989. Effect of ionophores on ruminal fermentation. Appl. Environ. Microbiol. 55:1-6.

Stahl, D. A., B. Flesher, H. R. Mansfield and L. Montgomery. 1988. Use of phylogenetically based hybridization probes for studies of ruminal microbial ecology. Appl. Environ. Microbiol. 54:1079-1084.

Stevenson, D. M. and P. J. Weimer. 2007. Dominance of Prevotella and low abundance of classical ruminal bacterial species in the bovine rumen revealed by relative quantification real-time PCR. Appl. Microbiol. Biotechnol. 75:165-174.

Tamminga, S. 1979. Protein degradation in the forestomachs of ruminants. J. Anim. Sci. 49:1615-1630.

Uwituze, S., G. L. Parsons, K. K. Karges, M. L. Gibson, L. C. Hollis, J. J. Higgins and J. S. Drouillard. 2011. Effects of distillers grains with high sulfur concentration on ruminal 
fermentation and digestibility of finishing diets. J. Anim. Sci. 89:2817-2828.

van Gylswyk, N. O. 1990. Enumeration and presumptive identification of some functional groups of bacteria in the rumen of dairy cows fed grass silage-based diets. FEMS Microbiol. Lett. 73:243-261.

Van Nevel, C. J. and D. I. Demeyer. 1977. Effect of monensin on rumen metabolism in vitro. Appl. Environ. Microbiol. 34:251257.

Van Nevel, C. J. and D. I. Demeyer. 1988. Manipulation of rumen fermentation. In: The Rumen Microbial Ecosystem (Ed. P. N. Hobson). Elsevier Applied Science, London, UK. pp. 387-443.

Van Soest, P. J. 1994. Nutritional ecology of the ruminant. 2nd edn. Cornell University Press, New York, New York.

Wallace, R. J. 1983. Hydrolysis of ${ }^{14} \mathrm{C}$-labelled proteins by rumen microorganisms and by proteolytic enzymes prepared from rumen bacteria. Br. J. Nutr. 50:345-355.

Wallace, R. J. and N. McKain. 1989. Analysis of peptide metabolism by ruminal microorganisms. Appl. Environ. Microbiol. 55:2372-2376

Wallace, R. J., R. Onodera and M. A. Cotta. 1997. Metabolism of nitrogencontaining compounds. In: The Rumen Microbial Ecosystem (Ed. P. N. Hobson and C. S. Stewart). Chapman \& Hall, London, England. pp. 283-323.
Weimer, P. J., D. M. Stevenson, D. R. Mertens and E. E. Thomas. 2008. Effect of monensin feeding and withdrawal on populations of individual bacterial species in the rumen of lactating dairy cows fed high-starch rations. Appl. Microbiol. Biotechnol. 80:135-145.

Whetstone, H. D., C. L. Davis and M. P. Bryant. 1981. Effect of monensin on breakdown of protein by ruminal microorganisms in vitro. J. Anim. Sci. 53:803-809.

Winter, K. A., R. R. Johnson and B. A. Dehority. 1964. Metabolism of urea nitrogen by mixed cultures of rumen bacteria grown on cellulose. J. Dairy Sci. 47:793-797.

Wolin, M. J. and T. L. Miller. 1988. Microbe-microbe interactions. In: The Rumen Microbial Ecosystem (Ed. P. N. Hobson). Elsevier Applied Science, London, UK. pp. 343-359.

Yang, C. M. and J. B. Russell. 1993a. Effect of monensin on the specific activity of ammonia production by ruminal bacteria and disappearance of amino nitrogen from the rumen. Appl. Environ. Microbiol. 59:3250-3254.

Yang, C. M. and J. B. Russell. 1993b. The effect of monensin supplementation on ruminal ammonia accumulation in vivo and the numbers of amino acid-fermenting bacteria. J. Anim. Sci. 71:3470-3476. 